\title{
Utilizing Service-Learning to Promote a Value Based Professional Nursing Curriculum
}

\author{
Catherine P. Corrigan, Andrea N. Kwasky \\ McAuley School of Nursing, College of Health Professions, University of Detroit Mercy, Detroit, USA \\ Email: ccerin@gmail.com
}

Received 10 September 2014; revised 6 October 2014; accepted 20 October 2014

Copyright $@ 2014$ by authors and Scientific Research Publishing Inc.

This work is licensed under the Creative Commons Attribution International License (CC BY).

http://creativecommons.org/licenses/by/4.0/

\section{c) (i) Open Access}

\begin{abstract}
This article will discuss the unique way in which nursing education at one Catholic University is distinctively value-driven with a focus on the meaning of Mercy and Jesuit traditions and how these philosophies translate into professional nursing practice. An innovative approach to a valuedriven education that incorporates the philosophy of the Mercy and Jesuit traditions in a professional nursing role is fostered with the teachings of Catherine McAuley and Ignatius Loyola and infused through the act of service-learning and reflection on the service-learning experience. Nursing students are educated from a perspective of historical tradition, spirituality, social justice, reflective thinking and a value-centered professional education, enriching their self-awareness toward the development of leadership behaviors. Linking the service-learning experience to nursing concepts within the Mercy and Jesuit traditions has demonstrated a deep sense of selfawareness, a high level of understanding of caring and the concept of nurses as leaders amongst the students at our university.
\end{abstract}

\section{Keywords}

Service-Learning, Mercy, Jesuit, Self-Awareness, Leadership

\section{Introduction}

"It is not the actual physical exertion that counts toward a man's progress, nor the nature of the task, but the spirit of faith with which it is undertaken" (Faith Quotes, 2012). Students who begin the nursing curriculum directly after high school commonly have little work experience prior to starting their course of study. As faculty teaching an "introduction to professional nursing and self-awareness" class for entry level nursing students, it is 
evident that many of the students are not aware of the depth of commitment that is required of them in their nursing career. Introducing service-learning at the beginning of the students' course of study allows them to interact with individuals who may be different from their own communities and backgrounds. The act of service-learning has been described as a course-based civic engagement project by students which meets community needs and is associated with reflecting on their service-learning occurrence, enriching their academic experience to ensure that they are well-equipped to fulfill the needs of their communities (Brammer \& Morton, 2014). Service-learning helps students to understand vulnerable populations, diversity, community, social justice, and become more self-aware of their own attitudes and beliefs. This opens up an opportunity for students to challenge any previously held assumptions. These are lessons that become the core of their nursing curriculum as students focus on relationship-based, person-centered care. By introducing students to the concept of service-learning early in their academic career and by helping them to identify how service is tied to the mission of a Catholic university and their chosen profession, students come to understand that they are receiving a valuedriven, mission-based education. In addition, the concepts of person-centered care, communication, team work and collaboration, evidenced based practices and the art of nursing are embedded throughout the course of study. The act of service-learning enriches students' understanding of these concepts by providing them with an experience that allows them to simultaneously put into practice the foundational concepts of what they learn in the classroom.

The mission statement of the School of Nursing leans heavily on the commitment to providing high quality, culturally sensitive health care services, to diverse populations in an urban context within the Mercy and Jesuit traditions. Service-learning helps students to achieve the mission by immersing them in an urban environment where they interact with vulnerable individuals, families and communities. Service-learning allows students to critically examine social issues and population diversity with an awareness of the impact that nurses can have in the community as well as within the hospital setting. An important aspect of the Mercy and Jesuit value-based, person-centered care includes spirituality and a holistic approach to each individual, inclusive of mind, body and spirit.

Incorporating spirituality into the course content emphasizes the significance of spiritual care in nursing. Throughout the introductory nursing course, didactic lectures are facilitated by the Sisters of Mercy. Nursing students are guided by faculty through the practice of reflection to increase their self-awareness and to care for themselves and each other, which is vital to their ability to provide spiritual care and to incorporate the intrinsic human dignity perspective (Connell Meehan, 2012) into their practice-central to the nursing profession. The students are taught to recognize each person's innate dignity which is paramount to the Catholic tradition and the importance of sensitivity and compassion towards the eradication of incompetent, insensitive and sometimes abusive healthcare toward the vulnerable and the sick (Connell Meehan). The purpose of this article is to present an understanding of how to incorporate service-learning within a Bachelors of Nursing Science program from the perspective of linking the experience to nursing concepts within the Mercy and Jesuit traditions.

\section{Mercy and Jesuit Values and Founding Principles}

Following in the traditions of their founder Catherine McAuley, the Sisters of Mercy are committed to serving God's people, especially the sick, poor and uneducated. Conscious of people's rights, their mission seeks to help people overcome obstacles that sometimes prevent them from living full and dignified lives (Flaherty, 2010). The Sisters are committed to both spiritual (comforting the afflicted, instructing the ignorant) and corporal (visiting the sick, welcoming the stranger) works of Mercy that embraces a multicultural and international reality. In the spirit of mercy and justice, the Sisters of Mercy carry on the work of McAuley providing for those on the margins of society (Flaherty).

The Jesuits (Society of Jesus) have been known as the "schoolmasters of Europe" for several centuries, encouraging the pursuit of knowledge in order to serve others (Jesuit Tradition, 2010). A Jesuit education seeks to challenge students to think independently, test commonly accepted knowledge and to be curious. Students are encouraged to grow personally, be responsible citizens and make sound judgments as they evolve as leaders. Students educated in the Jesuit tradition learn the importance of balance, interdependence with self-reliance and knowledge with spirituality, mind and heart.

Students educated within the Mercy and Jesuit traditions are charged with providing services with meaning and thought, based on the values of their Catholic university. Purposeful integration of course concepts such as 
caring and compassion with their service-learning experience have proven to be a very valuable teaching and learning strategy. Students gain an appreciation for the art of nursing and the significance of recognizing the uniqueness of each person from a holistic perspective that encompasses mind, body and spirit. The importance of the mission and being a conscientious member of their community is integrated into the curriculum. This allows students to gain an appreciation and understanding for the founding principles of their value-driven education and informs them about the all-encompassing education that they are receiving in preparation to become citizens of the world. Albeit Catholic, the university is very student centered with a respect for the diversity of religious and cultural beliefs of the student body. Acknowledging and celebrating the uniqueness of individuals and diversity of our community is part of the values that we impart through service-learning and a mission-driven university education.

\section{Literature Review}

A collaboration of teaching and learning to enhance academic and personal growth while engaging in civic service and reflecting and examining specific outcomes of that service enhances both the quality of learning as well as the service. Service-learning facilitates learning experiences that assists students in the development of critical thinking skills with the application of what they learn in class to real-world situations. Service-learning is not a replacement for academic tuition, rather it enhances it. Students in service-learning courses report higher course satisfaction than students in non-service-learning courses. Additionally, they have been reported as having a higher academic performance (Peters, 2011).

The literature provides a plethora of evidence to support service-learning as being a powerful pedagogical approach at the college level (Amerson, 2010; Foli, Braswell, Kirkpatrick, \& Lim, 2014; Fowler, 2013; Trail Ross, 2012), and an important component of nursing education (Groh, Stallwood, \& Daniels, 2011). Evidence indicates that service-learning fosters students' interest in strengthening their commitment to working for social changes and pursuing socially responsible work (Seider, Gillmore, \& Rabinowicz, 2012). One of the key components of The Future of Nursing document urges the nursing profession to get involved in the transformation of healthcare (Institute of Medicine, 2010). With the Affordable Care Act, the emphasis is on preventative medicine and nurses can play an essential role as coaches of healthy living. An introduction to servant leadership with service to the community helps nursing students appreciate the meaning of becoming a professional nurse and their responsibility to the public to negotiate the transformation that is occurring in the healthcare arena. The complexity of issues facing our communities, and the diversity of the individuals and families that they will be caring for are familiar encounters of their community service experience.

Students work in all capacities sharing interdisciplinary encounters with members of the community organizations that provide unyielding assistance to vulnerable populations. Faculty has noted the positive outcomes of the service-learning experience. Reluctant students soon become willing participants who empathize with the population they serve. Students have reported the interprofessional service-learning experience as making them feel more confident and competent, achieving a better cultural understanding and an increased ability to problem-solve (Matthews, Parker, \& Drake, 2012).

The Metaparadigm of Nursing (Chitty \& Black, 2010) and the Social Change Model (Wagner, 2006) provide the framework for the service-learning experience. The relationship between the four concepts of the Metaparadigm of Nursing: patient (person), environment, health and nursing, defines professional nursing practice. The association between these concepts can be identified in almost all conceptual models and philosophies of nursing. Concepts associated with the metaparadigm are diversity, cultural awareness (persons), community (environment), vulnerable populations, person-centered care, caring, empathy, communication, teamwork and collaboration, social justice, evidence based practice and the holistic approach (mind, body, spirit) to caring for people (nursing). Baccalaureate nursing students, even at the introductory level, are challenged to identify how these concepts are defined and work together with respect to the service-learning experience.

The Social Change Model (SCM) is founded on relationships and collaboration. It recognizes a nonhierarchical approach to leadership and encompasses the three main concepts of individual, group and community leadership values (Astin, 1996). The SCM applies to service-learning, by framing service as an individual leadership experience, where students gain self-awareness through reflective practice. Students become aware of their potential impact on social issues in the communities that they serve and then reflect on possible strategies they—as individuals — can do to become change agents to solve an issue. 
Throughout the semester "self-awareness" is emphasized; awareness is examining one's own biases and prejudice (Amerson, 2010); for instance, students are taught to become aware of their biases and how their precon ceived judgments could affect the care they provide to their patients. An emphasis is placed on concepts such as caring, empathy and cultural awareness, communication and the holistic approach of nursing. Compassion through service- a commitment to serve and understand people's needs-is the ultimate goal of the servicelearning encounter.

\section{Teaching and Learning via Service-Learning}

Many suburban students have had little exposure to the high poverty level and prevalence of vulnerable populations within an urban context. Following in the Mercy and Jesuit traditions, faculty strives to develop students who are both compassionate and competent, embracing concepts such as social justice and spirituality. The approach to service-learning encompasses Florence Nightingale's ethos to nursing education that balances the most current scientific development of the time with the spiritual development of the student. Spirit is acknowledged as being that vital or animating force in one's life - the integrating factor and the glue that holds it all together. Nursing was viewed as a "calling" where one was obligated to use one's talents and skills for others since they are gifts from God. Catherine McAuley's model of nursing called "Careful Nursing" focused on attention to the whole person-caring for the physical and emotional needs was always accompanied by sharing religious practices. The demeanor of the nurse was described as one of "contagious calmness". The nurse was to bring a sense of peace and calm to patients in the midst of their physical, emotional and spiritual distress (Meehan, 2012). The essence of spiritual care-giving is the capacity to enter into the world of others and respond with feeling. The message is clear: serve with a caring and compassionate approach.

The pedagogical method employed in the service-learning class begins with thought-provoking exercises. The students are invited to participate in an exercise of "deep listening" where they sit quiet, ask for the light, then reflect on how they feel about a situation or person for that day. Students are asked to listen deeply to what their inner light is telling them and to choose what they will take from the experience as well as what they could change. The exercise transcends diverse spiritual philosophies of most nurses with the belief that spiritual experiences can be captured during times of silence (Connell Meehan, 2012). Exercises such as this, helps students recognize their own thoughts, beliefs, and previously held assumptions. Following the though-provoking exercise, students go on to partake in the act of service.

Students in this introductory nursing course are required to complete six hours of service within a small group. A list of service-learning sites is carefully selected by the faculty, so that students can gain experience with a variety of social issues. Students are allowed to choose their own site with faculty guidance. The selection of sites is intentional, so that predictable experiences can be orchestrated by the professors to meet the objectives of the course. The chosen sites allow students to interact with individuals who may be vulnerable, marginalized or disenfranchised. The course faculty strives to make sure students are exposed to people in need across racial and social strata, as a result of various societal issues and personal choices.

The act of serving exposes students to social situations that require them to examine strategies toward improving the current state of social inequity. The issue of social justice is presented early in their course of study. Students, not previously exposed to healthcare inequity, often experience it first hand at their service-learning site. Exposure to service sites such as soup kitchens, boys and girls clubs, nursing homes, food banks and teen pregnancy centers are some of the sites served. Students' experiences at these sites supports Catholic social teaching within the Jesuit traditions that seeks to instill in them a sense of solidarity with one another (White, 2012) where learning encompasses contact with the real world rather than learning solely through concepts introduced within the classroom setting.

Students are required to work in groups. Early in the course, students are educated about "group dynamics" and the "stages of team development" that prepares them for the interdisciplinary approach to caring for patients. They are encouraged to take ownership of the service-learning arrangements within their group to enable them to develop some organizational and time management skills. Group dynamics can be challenging and the students are charged with developing problem-solving skills for issues that may arise. Faculty purposely step back to allow students to solve their own group dynamics, intervening only when necessary.

Before and after conducting their service, students are required to individually reflect on both their expectations and the realities of their experience. Reflection (Spiritual Exercise) was practiced by Saint Ignatius, with 
the concept that the reasoning for one self brings about a better understanding or a transformation of the self (Sluhovsky, 2013). Emulating the concept of spiritual exercise, students are required to reflect on their service to deepen the service-learning experience beyond being a mere task. There are many meaningful and challenging reflection activities, for instance: 1) inquiring what the student might expect to be the benefit of the servicelearning experience; 2) querying what strategies would benefit the population served; 3) describing a challenging event; 4) indicating why this learning experience is significant (Jesuit Tradition, 2010). An effective approach for enhancing reflection is based on four " $\mathrm{C}$ " core elements - the "Four C's" criteria (continuous, connected, challenging and contextualized). The aim is to "challenge" the student to think in new ways on a more philosophical level by inquiring about their perceptions and impressions of their experiences as they are asked to identify relevant concepts (contextual) relating to their service-learning. Ongoing (continuous) reflection throughout the duration of the course provides students the opportunity to link abstract new nursing concepts via hands on experience with real life issues (connected) (Peters, 2011). The guided reflections have been beneficial in transforming the novice thinking of entry-level nursing students, to becoming introspective and more selfaware of their own values, beliefs and biases.

After the students conduct their service, they are charged with presenting their service-learning experience in class. Freedom of expression is encouraged - tapping into their group members' artistic and creative talents can make this endeavor interesting and exciting rather than just another assignment. Suggestions are provided for the final group presentation and include presenting through poetry, either writing a poem or citing a current poem and describing the association of service-learning and nursing concepts to the poem; creating a picture (students are encouraged to think about using shadows) to illustrate the association; designing a box with key values or dimensions labeled on the outside and inside have slips of paper that reflect the service-learning experience (caring, compassion, advocacy for instance) - team members can draw out a slip of paper and briefly talk about that concept; act out a scenario of significance that occurred during their service; make an art piece, for example a dream catcher that represents key learning; weave a piece of fabric to illustrate connections; music; creative writing; stained glass, or a poster board presentation are all encouraged. The presentations are moderated by faculty to further emphasize the course concepts outlined in the course objectives and assist the students to understand that service to others is the bases for their chosen profession. The applicable course objectives include describing concepts of 1) person-centered care; 2) communication; 3) teamwork and collaboration; 4) diversity; 5) the art of nursing.

Some students become overwhelmed with emotion when presenting their experience; mainly because they may have been exposed to a social issue that they have never confronted, or because they are so appreciative for the opportunity to dispel their own long-held preconceived notions. The process by which students can openly share their previous biases and identify that perhaps their judgments were not warranted, is transformational, both for the individual and the class at large. By applying their thoughts about "the person" and what the individual was experiencing at that time and place in their lives that they required assistance, it becomes evident that students are compelled to a deeper understanding of the importance of individualizing each human being and what it means to really care.

Throughout the semester "self-awareness" is emphasized. Students are taught about biases and how their preconceived judgments could affect how they care for their patients. An emphasis is placed on concepts such as caring, empathy, cultural awareness, communication and the holistic approach to nursing. Nursing faculty utilized practice-based experiences to generate lively dialogue and stimulate discussions related to class content.

The mission of the university is to be Catholic, Mercy, and Jesuit; urban and student-centered. Service-learning is introduced as a means of enhancing academic content as well as benefiting the community with an altruistic approach that reflects the Catholic tradition for the common good of the world community. The Sisters of Mercy align the meaning of service for the students in the introductory nursing class by reinforcing and embracing the mission of the university that seeks to integrate the spiritual development of their students.

\section{The Service-Learning Experience}

The aim of the service-learning experience is embedded in real-world scenarios that students are encouraged to critically evaluate. Critical self-reflection allows nurses to develop and cultivate a caring mindset - the start of a great foundation for nursing care (Vanlaere \& Gastmans, 2007). Included in the Jesuit traditions are the notions of reflection and curiosity which are more commonly referred to in the nursing field as critical thinking. Critical 
thinkers decide what to believe or do, which requires the use of reflection, inquisitiveness, open-mindedness, flexibility, clarity, judgment and honesty in facing personal biases, to make rationale, well-informed decisions. Critical thinkers are willing to reconsider, provide order to complex matters and are diligent in seeking pertinent answers (An \& Yoo, 2008). Care-giving has become very complex and new nurses must learn how to think critically within mentally appropriate structures that provide them with processes to work within (Bryon, de Casterlé, Gastmans, Steeman, \& Milisen, 2008). By lecturing on a subject and exposing nursing students to servicelearning, the idea of critical thinking that bridges the gap between theory and practice for the new nurse, is emphasized. The act of service and reflection has proven to be an effective strategy in taking students' learning from levels of identification and application to the higher levels of analysis and evaluation (Ash et al., 2005) as identified in Bloom's Taxonomy (Brewer \& Brewer, 2010).

Social interaction opportunities manifest with students serving meals to culturally diverse and often economically depressed people. The complexity of some vulnerable populations requires flexibility and balance. Students have reported on confliction of values and reliance on the ethical principles of justice and utilitarianism, where utilities are maximized for the good of all. An example was when a homeless man wanted more than one sandwich with his soup. The student wanted to give him extra; however the ethical principle of justice was conflicted by the necessary structure of the soup kitchen where only one sandwich per guest was allowed so that there would be enough food to go around. Situations like this provide opportunity for students to evaluate ethical dilemmas. Students frequently report changes in their attitude toward the disadvantaged they served. One student realized his bias toward single pregnant teenagers and young women, indicating the service-learning experience in a home for unwed mothers changed his opinions when he encountered a pregnant rape victim.

At the end of the course, students provide feedback in a faculty prepared questionnaire. Students' feedback related directly to the course objectives for instance, self-awareness: "I got comfortable with mentally disabled people... being aware of other's needs and being self-aware and how that can help me in patient care"; "service-learning made me more aware about myself, such as my own biases, stereotypes and things I would like to change"; "I learned that everyone deserves help, no matter what color or race they are"; and compassion: "I feel that I gained a lot of compassion, empathy and patience during my time at Angles Place".

\section{Nurses as Leaders}

Nurses are being called upon to become transformational leaders (Institute of Medicine, 2010). Baccalaureate level nurses who demonstrate leadership behaviors are sought after by institutions pursuing Magnet recognitiona designation of excellence denoting a progressive organization that values nurses' decision-making and health care driver capabilities (Foli et al., 2014). The nursing literature describes community participation associated with reflection, as an integral pedagogical approach for the development of leadership behaviors (Foli et al.). The transformational leader is described as being charismatic, self-confident and a visionary who recognizes the strengths and talents of their followers and motivates and encourages them to work to their full potential (Northouse, 2013). Students who have participated in service-learning have described concepts of encouragement and motivation: "I learned to inspire and let the kids know we are all connected in some way to help each other". They also benefitted from teamwork that is essential in nursing practice: "we learned teamwork; working together."

Reflecting on their experiences in their service-learning sites, students write about the happenings of the event, but also a vast array of human characteristics and interactions they have observed within some organizations. Homogeneity is the enemy of truth (Porter O'Grady \& Mallock, 2011) and the aim is to expose the students to diverse cultural experiences and situations, sometimes quite shocking to them; nevertheless, students' feedback indicated service-learning as a highly impressionable experience that achieved the objective of increasing selfawareness toward leadership behaviors: "I proved to myself that I am a natural leader and can handle dealing with different types of people" and "I believe the experience aided me in my true calling to serve others". Teaching students to approach each individual from a holistic perspective and having sensitivity to their needs, will in turn benefit families and communities they will serve as professional nurses.

\section{Conclusion}

Service-learning is a teaching pedagogy that can greatly enhance the learning experience for the student who benefits from an experiential immersion. This paper introduced one way in which service-learning can be operationalized by developing students' ability to relate classroom content to real-life scenarios. Both the Mercy and 
Jesuit ideals provide a framework for reflection-it is within that reflection that students become more selfaware, which will provide them with a solid foundation to become future leaders of change within the health care arena. Service-learning has proven to be very beneficial to introductory nursing students from many perspectives, most importantly, they become more sensitive to the needs of others and go on to serve the most vulnerable of our society with empathy and compassion.

\section{References}

Amerson, R. (2010). The Impact of Service-Learning on Cultural Competence. Nursing Education Perspectives, 31 , 18-22.

An, G., \& Yoo, M. (2008). Critical Thinking and Learning Styles of Nursing Students at the Baccalaureate Nursing Program in Korea. Contemporary Nurse: A Journal for the Australian Nursing Profession, 29, 100-109. http://dx.doi.org/10.5172/conu.673.29.1.100

Ash, S. L., Clayton, P. H., \& Atkinson, M. P. (2005). Integrating Reflection and Assessment to Capture and Improve Student Learning. Michigan Journal of Community Service Learning, 11, 49.

Astin, H. S. (1996). Leadership for Social Change. About Campus, 1, 4-10.

Brammer, L. R., \& Morton, A. (2014). Course-Based Civic Engagement: Understanding Student Perspectives and Outcomes. International Journal for the Scholarship Of Teaching \& Learning, 8, 1-22.

Brewer, P. D., \& Brewer, K. L. (2010). Knowledge Management, Human Resource Management, and Higher Education: A Theoretical Model. Journal of Education for Business, 85, 330-335. http://dx.doi.org/10.1080/08832321003604938

Bryon, E., de Casterlé, B., Gastmans, C., Steeman, E., \& Milisen, K. (2008). Mealtime Care on a Geriatric-Psychiatric Ward from the Perspective of the Caregivers: A Qualitative Case Study Design. Issues in Mental Health Nursing, 29, 471-494. http://dx.doi.org/10.1080/01612840801981272

Chitty, K. K., \& Black, B. P. (2010). Professional Nursing: Challenges \& Concepts. St. Louis: Elsevier Saunders, 321.

Connell Meehan, T. (2012). Spirituality and Spiritual Care from a Careful Nursing Perspective. Journal of Nursing Management, 20, 990-1001. http://dx.doi.org/10.1111/j.1365-2834.2012.01462.x

Faith Quotes (2012). The Catholic Reader. Last Checked 28 JUNE 2014. http://thecatholicreader.blogspot.com/2012/12/faith-quotes.html

Flaherty, T. A. (2010). Australian Sisters of Mercy as Missionaries in Papua New Guinea: Following Paths of Mercy beside Peoples of Ancient Melanesian Cultures. Australasian Catholic Record, 87, 47-60.

Foli, K. J., Braswell, M., Kirkpatrick, J., \& Lim, E. (2014). Development of Leadership Behaviors in Undergraduate Nursing Students: A Service-Learning Approach. Nursing Education Perspectives, 35, 76-82. http://dx.doi.org/10.5480/11-578.1

Fowler, D. L. (2013). Service-Learning and Nursing Professional Values Development: An Experimental Research Study. Nursing Education Perspectives, 34, 50-51. http://dx.doi.org/10.5480/1536-5026-34.1.50

Groh, C. J., Stallwood, L. G., \& Daniels, J. (2011). Service-Learning in Nursing Education: Its Impact on Leadership and Social Justice. Nursing Education Perspectives, 32, 400-405. http://dx.doi.org/10.5480/1536-5026-32.6.400

Institute of Medicine (2010). The Future of Nursing: Leading Change, Advancing Health. http://www.iom.edu/Reports/2010/The-Future-of-Nursing-Leading-Change-Advancing-Health.aspx

Jesuit Tradition (2010). Xavier University. http://www.xavier.edu/undergraduate-admission/documents/jesuit-tradition-brochure.pdf

Matthews, R. L., Parker, B., \& Drake, S. (2012). Healthy Ager: An Interprofessional, Service-Learning, Town-and-Gown Partnership. Nursing Education Perspectives, 33, 162-165. http://dx.doi.org/10.5480/1536-5026-33.3.162

Meehan, T. (2012). The Careful Nursing Philosophy and Professional Practice Model. Journal of Clinical Nursing, 21, 2905-2916. http://dx.doi.org/10.1111/j.1365-2702.2012.04214.x

Northouse, P. G. (2013). Leadership: Theory and Practice (6th ed.). Thousand Oaks, CA: Sage.

Peters, K. A. (2011). Including Service Learning in the Undergraduate Communication Sciences and Disorders Curriculum: Benefits, Challenges, and Strategies for Success. American Journal of Audiology, 20, S181-S196. http://dx.doi.org/10.1044/1059-0889(2011/10-0031)

Porter-O’Grady, T., \& Mallock, K. (2011). Quantum Leadership: Advancing Innovation, Transforming Health Care. Sudbury, MA: Jones \& Bartlett, 51-57.

Seider, S. C., Gillmor, S., \& Rabinowicz, S. (2012). The Impact of Community Service Learning upon the Expected Political Voice of Participating College Students.

http://people.bu.edu/seider/Consolidated\%20papers/Expected\%20Political\%20Voice\%20Paper\%20Final\%20Proofs.pdf

Sluhovsky, M. (2013). St. Ignatius of Loyola's Spiritual Exercises and Their Contribution to Modern Introspective Subjec- 
tivity. Catholic Historical Review, 99, 649-674.

Trail Ross, M. (2012). Linking Classroom Learning to the Community through Service Learning. Journal of Community Health Nursing, 29, 53-60. http://dx.doi.org/10.1080/07370016.2012.645746

Vanlaere, L., \& Gastmans, C. (2007). Ethics in Nursing Education: Learning to Reflect on Care Practices. Nursing Ethics, 14, 758-766. http://dx.doi.org/10.1177/0969733007082116

Wagner, W. (2006). The Social Change Model of Leadership: A Brief Overview. Trinity University.

http://web.trinity.edu/Documents/student_affairs_docs/Assessments/Social $\% 20$ Change $\% 20$ Model $\% 20$ of $\% 20$ Leadership $\%$ 20-\%20A\%20Brief\%20Overview\%20(Wagner). $\overline{\text { pdf }}$

White, J. (2012). The International Baccalaureate Diploma Programme in U.S. Catholic High Schools: An Answer to the Church's Call to Global Solidarity. Catholic Education: A Journal of Inquiry \& Practice, 15, 179-206. 
Scientific Research Publishing (SCIRP) is one of the largest Open Access journal publishers. It is currently publishing more than 200 open access, online, peer-reviewed journals covering a wide range of academic disciplines. SCIRP serves the worldwide academic communities and contributes to the progress and application of science with its publication.

Other selected journals from SCIRP are listed as below. Submit your manuscript to us via either submit@scirp.org or Online Submission Portal.
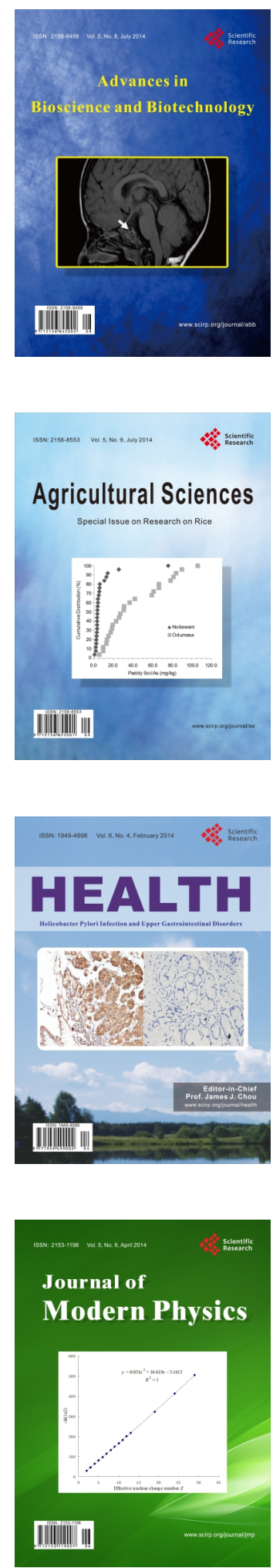
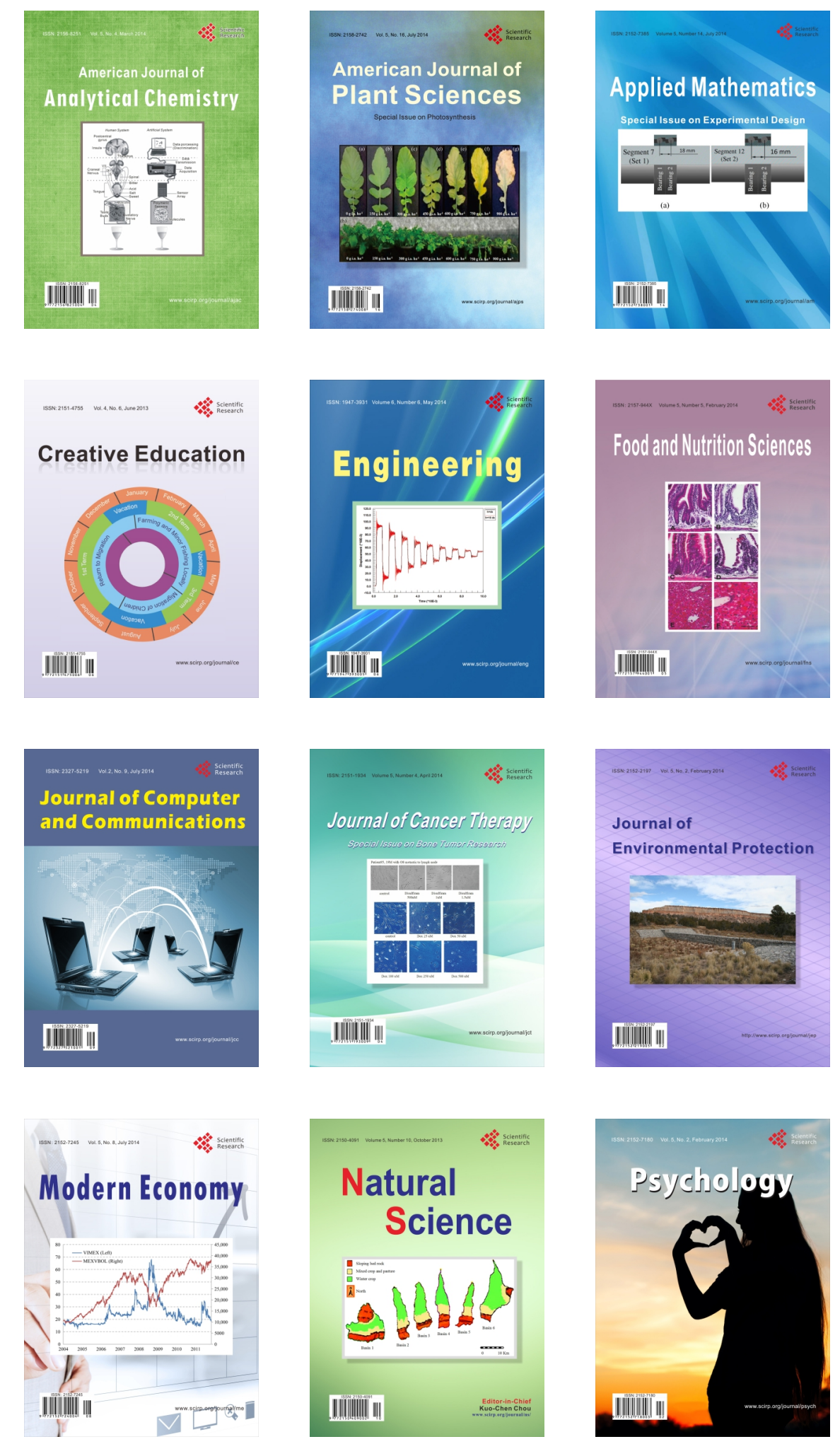